Research Article

\title{
The Prevalence and Outcome of Teenage Pregnancies at a Tertiary Care Teaching Hospital
}

\section{Prevalensi dan Luaran Kehamilan Remaja pada Rumah Sakit Pendidikan Tersier}

\author{
I Putu G Kayika, Farrah Lidyana \\ Department of Obstetrics and Gynecology \\ Faculty of Medicine Universitas Indonesia/ \\ Dr. Cipto Mangunkusumo Hospital \\ Jakarta
}

\begin{abstract}
Objective: To examine the prevalence as well as the maternal and perinatal outcome of teenage pregnancies.

Methods: For analyzing the prevalence of the teenage mothers, we used cross-sectional study design by evaluating the medical records of all pregnant mothers who went to the obstetric clinic of Dr.Cipto Mangunkusumo Hospital, Jakarta, Indonesia, during January 2014 until December 2016. For the outcome of the teenage mothers, we used retrospective study design by analysing medical records of teenage mothers who had delivery at the delivery ward of Dr. Cipto Mangunkusumo Hospital during January 2014 until December 2016. We compared their outcomes to outcomes of pregnant women aged 20 to 30 years old delivered at the same hospital in the same period. Maternal outcomes that were measured include preeclampsia, methods of delivery, anaemia, and postpartum haemorrhage, as well as perinatal outcomes including preterm delivery, and low birthweight.
\end{abstract}

Results: Among 3.578 out patients at Obstetric Clinic, RSUPN Dr. Cipto Mangunkusumo, we got 503 pregnant subjects, 16 $(3.2 \%)$ were teenagers. Among 520 subjects who had delivery, $78(15 \%)$ subjects were $\leq 19$ years old. Teenage pregnancy was significantly associated with anemia $(\mathrm{p}<0.05$, adjusted $\mathrm{OR}$ $=2,08)$ and low birthweight $(\mathrm{p}<0.05$, adjusted $\mathrm{OR}=1.83)$. Teenage pregnancy was not significantly associated with preeclampsia, methods of delivery, postpartum haemorrhage, and preterm delivery.

Conclusion: The prevalence of teenage pregnancy at Dr. Cipto Mangunkusumo Hospital was $3.2 \%$, and teenage mothers who had delivery was $15 \%$. Teenage mothers are at increased risk of anaemia and delivering low birth weight babies.

[Indones J Obstet Gynecol 2018; 6-4: 209-212]

Keywords: maternal outcome, perinatal outcome, prevalence, teenage pregnancies

\begin{abstract}
Abstrak
Tujuan: Untuk mengetahui prevalensi kehamilan remaja serta luarannya.

Metode: Untuk menganalisis prevalensi ibu remaja, kami menggunakan desain studi potong lintang dengan mengevaluasi rekam medis dari seluruh ibu hamil yang berobat ke klinik obstetri RSUPN Dr. Cipto Mangunkusumo pada periode Januari 2014 sampai Desember 2016. Pada luaran ibu hamil, kami menggunakan desain studi retrospektif dengan menganalisis rekam medis ibu remaja yang bersalin di RSUPN Dr. Cipto Mangunkusumo pada periode yang sama. Luaran ibu remaja dibandingkan dengan ibu yang bersalin berusia 20-30 tahun. Luaran ibu yang kami ukur meliputi preeklamsia, metode persalinan, anemia, perdarahan pascapersalinan, sedangkan luaran perinatal yang kami ukur meliputi kelahiran prematur dan BBLR.
\end{abstract}

Hasil: Dari seluruh 3.578 pasien di Poliklinik Obstetri RSUPN Dr. Cipto Mangunkusumo, diperoleh 503 subjek yang hamil, sebanyak 16 (3,2\%) subjek adalah remaja. Dari seluruh 520 subjek yang bersalin, $78(15 \%)$ subjek adalah remaja. Kehamilan remaja berhubungan signifikan dengan anemia $(p<0,05$, adjusted $O R=2,08)$ dan BBLR ( $p<$ 0,05 , adjusted $O R=1,83$ ). Kehamilan remaja tidak berhubungan signifikan dengan preeklamsia, metode persalinan, perdarahan pascapersalinan, dan kelahiran prematur.

Kesimpulan: Prevalensi kehamilan remaja di RSUPN Dr. Cipto Mangunkusumo adalah 3,2\% dan persalinan remaja di RSUPN Dr. Cipto Mangunkusumo adalah 15\%. Ibu remaja berada pada peningkatan risiko anemia dan melahirkan bayi BBLR

[Maj Obstet Ginekol Indones 2018; 6-4: 209-212]

Kata kunci: kehamilan remaja, luaran ibu, luaran perinatal, prevalensi

\section{INTRODUCTION}

Teenage pregnancy, an important public health burden worldwide, is defined as a pregnancy occurring in females aged 10-19 years. Approximately, $11 \%$ of births worldwide are to teenagers aged 15-19 years, and more than 90\% of these births occur in low- and middle-income countries. Moreover, the majority of teenage mothers are unmarried, and numerous teenage pregnancies are unplanned. Teenage pregnancy is associated with increased risk of poor maternal and fetal complications, including preterm birth, low birth weight, preterm premature rupture of 
membranes (PPROM), preeclampsia, low Apgar scores, and perinatal mortality. However, previous studies have produced contradictory findings regarding whether the adverse pregnancy outcomes among teenage mothers are caused by their biological immaturity or poor socio-environmental factors. ${ }^{1-3}$ To this date, studies regarding the complications of teenage pregnancy in Jakarta, Indonesia, are scarce. This study is aimed to investigate the prevalence as well as the maternal and perinatal outcome of teenage pregnancies.

\section{METHODS}

For analysing the prevalence of the teenage mothers, we used cross-sectional study design by evaluating the medical records of all pregnant mothers who went to the Women's Health clinic of Dr. Cipto Mangunkusumo Hospital, Jakarta, Indonesia, during the period between January 2014 and December 2016. For the outcome of the teenage mothers, we used retrospective study design by analysing medical records of teenage mothers who had delivery at the delivery ward of Dr. Cipto Mangunkusumo Hospital during January 2014 until December 2016. We compared their outcomes to outcomes of pregnant women aged 20 to 30 years old delivered at the same hospital in the same period. Maternal outcomes that were measured include preeclampsia, methods of delivery, anaemia, and postpartum haemorrhage, as well as perinatal outcomes including preterm delivery and low birthweight.

\section{RESULTS}

A total of 503 subjects were recruited for this study. The prevalence of teenage pregnancy was $3.2 \%$. For the prospective study, a total of 520 subjects were included. Of these subjects, 78 $(15 \%)$ were teenage mothers $(\leq 19$ years old). Demographic characteristics of the subjects who delivered are presented in Table 1.
Table 1. Demographic Characteristics of Subjects who Delivered

\begin{tabular}{|c|c|c|}
\hline & & $\begin{array}{l}\text { n (mean/ } \\
\text { range) }\end{array}$ \\
\hline Mean age & & $24(14-30)$ \\
\hline \multirow[t]{2}{*}{ Age category } & Teenagers & $78(15.0)$ \\
\hline & Adults & $442(85.0)$ \\
\hline \multirow[t]{2}{*}{ Marital age } & $<20$ yo & $233(45.2)$ \\
\hline & $>20$ yo & 282 (54.8) \\
\hline \multirow[t]{3}{*}{ Education } & Elementary high school & $10(1.9)$ \\
\hline & Junior high school & $84(16.2)$ \\
\hline & High school & 426 (81.9) \\
\hline \multirow[t]{2}{*}{ Marital status } & Married & $515(99.0)$ \\
\hline & Unmarried & $5(1.0)$ \\
\hline \multirow[t]{2}{*}{ Employment } & Employed & $43(8.3)$ \\
\hline & Unemployed & 477 (91.7) \\
\hline \multirow{2}{*}{$\begin{array}{l}\text { Contraceptive } \\
\text { methods }\end{array}$} & Yes & $106(20.4)$ \\
\hline & No & $414(79.6)$ \\
\hline \multirow[t]{4}{*}{ Delivery methods } & Vaginal delivery & 228 (43.8) \\
\hline & Vacuum-assisted delivery & $10(1.9)$ \\
\hline & Forceps-assisted delivery & $14(2.7)$ \\
\hline & Cesarean section & 268 (51.5) \\
\hline \multirow{2}{*}{$\begin{array}{l}\text { Antenatal care } \\
\text { visits attendance }\end{array}$} & Yes & 517 (99.4) \\
\hline & No & $3(0.6)$ \\
\hline \multirow[t]{2}{*}{ Parity } & Nulliparous & 195 (37.5) \\
\hline & Multiparous & $325(62.5)$ \\
\hline \multirow[t]{2}{*}{ Delivery methods } & Spontaneous & 228 (43.8) \\
\hline & Nonspontaneous & $292(56.2)$ \\
\hline \multirow[t]{2}{*}{ Anemia } & Yes & $109(21.0)$ \\
\hline & No & $411(79.0)$ \\
\hline \multirow[t]{2}{*}{ Preterm birth } & Yes & $216(41.5)$ \\
\hline & No & 304 (58.5) \\
\hline \multirow[t]{2}{*}{ Low birthweight } & Yes & $196(37.7)$ \\
\hline & No & $324(62.3)$ \\
\hline \multirow{2}{*}{$\begin{array}{l}\text { Postpartum } \\
\text { haemorrhage }\end{array}$} & Yes & $31(6.0)$ \\
\hline & No & 489 (94.0) \\
\hline \multirow[t]{2}{*}{ Preeclampsia } & Yes & $86(16.5)$ \\
\hline & No & $434(83.5)$ \\
\hline
\end{tabular}

In this study, we found significant association between teenage pregnancy and anemia as well as low birthweight. The association between teenage pregnancy and fetomaternal outcomes is presented in Table 2. 
Table 2. Association between Teenage Pregnancy and Fetomaternal Outcomes

\begin{tabular}{lcccc}
\hline \hline & Teenage $(\mathbf{n}=\mathbf{7 8})$ & Adults $(\mathbf{n}=\mathbf{4 4 2})$ & p value & Adjusted 0R (95\% CI) \\
\hline Preeclampsia & $11(14.1 \%)$ & $67(15.2 \%)$ & 0.530 & $1.08(0.51-2.29)$ \\
Anemia & $25(32.1 \%)$ & $52(11.8 \%)$ & 0.007 & $2.08(1.22-3.54)$ \\
Nonspontaneous delivery methods & $36(46.2 \%)$ & $256(57.9 \%)$ & 0.924 & $1.03(0.60-1.76)$ \\
Preterm delivery & $44(56.4 \%)$ & $172(38.8 \%)$ & 0.148 & $1.48(0.87-2.53)$ \\
Low birthweight & $42(53.8 \%)$ & $154(34.8 \%)$ & 0.026 & $1.83(1.08-3.13)$ \\
Postpartum hemorrhage & $0(0 \%)$ & $31(73,8 \%)$ & 0.016 & - \\
\hline \hline
\end{tabular}

\section{DISCUSSION}

In this study, the prevalence of teenage pregnancy was 3.2\%. This number is lower compared to those in Indonesia, Malaysia, and Thailand, which were amounted to $4.8 \%, 0.6 \%$, and $4.1 \%$, respectively. 4 This might be due to better socioeconomic status as well as the education levels in Jakarta, compared to other cities in Indonesia. According to the Indonesian Basic Health Research (Riskesdas) 2013, 2.6\% female aged 10-54 years married below the age of 15 years. Moreover, $23.9 \%$ of women married at the age of 15-19 years. ${ }^{5}$

The incidence of adolescents who gave birth at Dr. Cipto Mangunkusumo Hospital was 15\%. This number is significantly higher compared to the teenage pregnancy prevalence at the same hospital. This might occurs because Dr. Cipto Mangunkusumo hospital is a tertiary care center; thus, pregnant teenagers are often referred to this hospital, despite attending another hospital for routine antenatal care.

Preeclampsia, which occurs in $2-8 \%$ of all pregnancies, is a specific multisystemic and multifactorial condition in pregnancy that increases the mortality and morbidity of the mother as well as the fetus. The risk factors include younger age, nulliparity, and obesity. ${ }^{6}$ A previous study suggested that folic acid supplementation in early pregnancy may decrease the risk of developing preeclampsia, particularly in those with body mass index below $25 \mathrm{~kg} / \mathrm{m}^{2}{ }^{7}$ In this study, we did not find significant association between teenage pregnancy and preeclampsia ( $\mathrm{p}>0.05$, adjusted OR $=1.08)$. This is similar to a previous study conducted by Socolov et al. which found no significant differences in pregnancy comorbidity, chronic hypertension, gestational hypertension, preeclampsia, and eclampsia, between teenage and adult mothers. ${ }^{8}$ Torvie et al., Traisrisilps et al.,
Dedecker et al., Gortzak-Uzan et al., and Gupta et al. also found similar findings. ${ }^{9-13}$

Anaemia is a common complication in teenage pregnancy. ${ }^{14}$ Chahande et al. reported that $72.6 \%$ of pregnant teenagers had anaemia. ${ }^{15}$ Osbourne et al. found significant increment in the incidence of anemia in teenage pregnancy compared to those aged $20-24$ years $(11.1 \%$ vs $5.2 \%, p<0.001)$. In our study, we found significant association between teenage pregnancy and anaemia ( $\mathrm{p}<$ 0.007 , adjusted OR $=2.08$ ). This is similar to a case-control study conducted by Akadiri et al., which found that the incidence of anaemia was significantly higher in teenage mothers. ${ }^{16}$ This might happened due to suboptimal nutritional status at the onset of pregnancy. Other two studies also found significant increment of anaemia in teenage mothers. ${ }^{17,18}$

We did not find significant association between teenage pregnancy and delivery method $(\mathrm{p}>0.05$, adjusted OR $=1.03$ ). Several studies found an increased risk of cesarean section in teenage pregnancy. This differs from three studies which found that teenage pregnancy was not significantly associated with increased cesarean section rate. ${ }^{19-}$ 21 Yadav et al. found decreased section rate in teenage pregnancy. In that study, there was a high incidence of prevalence, which may be associated with successful vaginal delivery. ${ }^{22}$

We did not find significant association between teenage pregnancy and preterm birth. However, we found significant association between teenage pregnancy and low birthweight. Bukulmez and Deren found that teenage pregnancy was not an independent risk factor of preterm birth ${ }^{23}$, while Tufail and Hasmi found that neonates born from teenage mothers had higher risk of intrauterine growth restriction $(5.3 \%$ vs $0 \%, \mathrm{p}=0.043) .^{24}$ Mahfouz et al. suggested that teenage mothers did 
not belong to the high-risk group if there was good quality antenatal care. The poor outcomes of teenage pregnancy might be caused by low socioeconomic status, lack of reading interest, inadequate antenatal care, lack of social support, and low use of contraceptive method. ${ }^{16}$

We found statistically significant association between teenage pregnancy and postpartum haemorrhage $(p<0.016)$. However, no subject had postpartum haemorrhage in this study. Thus, it might be concluded that adult mothers are at higher risk of developing postpartum haemorrhage. Sgaili et al., Shah et al., Traisrisilp et al., and Leppalahti et al. did not find significant difference between teenage and adult mothers. ${ }^{9-12}$

Our limitations include lack of measurement of antenatal care attendance. We also used retrospective study design. Thus the reliability was lower compared to prospective study.

\section{CONCLUSIONS}

The prevalence of teenage pregnancy and teenage mothers who delivered at Dr. Cipto Mangunkusumo Hospital were $3.2 \%$ and $15 \%$, respectively. Teenage mothers are at an increased risk of developing anaemia and delivery low-birthweight babies.

\section{REFERENCES}

1. World Health Organization. Adolescent pregnancy - Unmet needs and undone deeds: a review of the literature and programmes. WHO Press. 2007: 99.

2. World Health Organization. Adolescent pregnancy: issues in adolescent health and development. WHO Press. 2004: 72.

3. Panagopoulos P, Bakalianou K, Davou E, Iavazzo C, Paltoglou G, Liapis A. Adolescent Pregnancy in a Greek Public Hospital During a Six-year Period (2000-2005): A Retrospective Study. J Pediatr Adolesc Gynecol. 2008; 21: 4.

4. World Health Organization. World Health Statistics. 2014.

5. RI BK. Riset Kesehatan Dasar. In: RI BK, editor. Jakarta 2013.

6. Paré E PS, McElrath TF, et al. Clinical risk factors for preeclampsia in the $21^{\text {st }}$ century. Obstet Gynecol 2014; 124: 8.

7. Martinussen MP BM, Triche EW, et al. Folic acid supplementation in early pregnancy and the risk of preeclampsia, small for gestational age offspring and preterm delivery. Eur J Obstet Gynecol Reprod Biol 2015; 195: 6.
8. Ellis BJ, Bates JE, Dodge KA, Fergusson DM, Horwood LJ, Pettit GS. Does Father Absence Place Daughters at Special Risk for Early Sexual Activity and Teenage Pregnancy? Child Dev. 2003; 74: 21.

9. K Traisrisilp JJ, S Luewan, T Tongsong. Pregnancy outcomes among mothers aged 15 years or less. J Obstet Gynecol Research. 2015; 41(11): 6.

10. Shah N KN, Rohra DK, Ahuja LK, Shuja S, Liaqat FN et al. Comparison of obstetric outcome among teenage and nonteenage others from three tertiary care hospitals of Sindh, Pakistan. J Pak Med Assoc 2011; 61: 5.

11. UNICEF. Young People and Family Planning: Teenage Pregnancy. Fact Sheet. In: UNICEF, editor. Malaysia: UNICEF; 2008.

12. S. Leppa, Lahti MG, M. Mentula, and O. Heikinheimo. Is teenage pregnancy an obstetric risk in a welfare society? A population-based study in Finland, from 2006 to 2011. BM] Open 2013;3:e003225. doi: 10.1136/bmjopen-2013003225

13. Gupta N KU, Bhal K. Teenage pregnancies: obstetric characteristics and outcome. Eur J Obstet Gynecol Reprod Biol. 2008; 137(2): 7.

14. World Health Organization. Programming for Adolescent Health and Development. In: WHO, editor. Geneva 1999.

15. Chahande MS JA, WadhvaSK, Ughade S. Study Of Some Epidemiological Factors In Teenage Pregnancy - Hospital Based Case Comparison Study. Ind J Community Med 2002; 27(3): 106.

16. Akadiri O BB, Ajenifuja KO. Obstetric outcome in teenage pregnancy in a free antenatal care setting in southwest $\mathrm{Ni}$ geria. NJOG. 2015; 19(1): 4.

17. Shah N KN, Rohra DK, Ahuja LK, Shuja S, Liaqat FN et al. Comparison of obstetric outcome among teenage and nonteenage others from three tertiary care hospitals of Sindh, Pakistan. J Pak Med Assoc 2011; 61: 5.

18. Thaithae S TR. Obstetric and perinatal outcomes of teenage pregnancies in Thailand. J Pediatr Adolesc Gynecol. 2011; 24(6): 5.

19. Bacci A MG, Machugo F. Outcome of teenage pregnancy in Maputo. Int J Gynecol Obstet 1993; 40: 5.

20. Lao TT HL. Obstetrics outcome of teenage pregnancies. Human Reprod. 1998; 13: 5.

21. Al Je. Obstetrics risk of pregnancy in women less than 18 years old. Obstet Gynecol 2000; 96(6): 5.

22. Yadav Sea. Adverse reproduction outcomes associated with teenage pregnancy. Mcgill J Med. 2008; 11(2): 4.

23. Bukulmez O DO. Perinatal outcome in adolescent pregnancies: a case-control study from Turkish university hospital. Eur J Obstet Gynecol Reprod Biol. 2000; 88(2): 6.

24. Tufail A, Hashmi, H. Maternal and perinatal outcome in teenage pregnancy in a community based hospital. Pak J Surg. 2008; 24: 4. 